\title{
The rationale for combining GLP-1 receptor agonists with basal insulin
}

Neale D Cohen MB BS, FRACP General Manager

Ralph Audehm MB BS, DipRACOG, GP Director ${ }^{2}$

Elaine Pretorius $M B$ ChB, FCP(SA), FRACP, Endocrinologist and General Physician

Joey Kaye MB BS, FRACP, PhD Endocrinologist

Leon H Chapman MB BS, FRACP Consultant Physician

Stephen Colagiur MB BS, FRACP Professor of

Metabolic Health

1Baker IDI Heart and Diabetes Institute, Melbourne, VIC

2 Dianella

Community Health,

Melbourne, VIC.

3 Diabetes and

Endocrine Services, Lyell McEwin Hospital, Adelaide, SA

4 Sir Charles

Gairdner Hospital

Perth, WA.

5 Boden Institute of Obesity, Nutrition, Exercise

and Eating Disorders,

Sydney, NSW.

neale.cohen@

bakeridi.edu.au

doi: 10.5694/mjal2.11856 strong he progressive nature of type 2 diabetes mellitus (T2DM) dictates the need for an individualised, stepped interventional approach. The current approach to treatment intensification includes the addition of increasingly complex insulin regimens that involve prandial insulin dosing. However, the more intensively diabetes is treated with many of the current treatment options, the greater the risk of hypoglycaemia, weight gain and, possibly, cardiovascular mortality. ${ }^{1-3}$ One of the key challenges in patient management is how to achieve glycaemic goals while mitigating these risks.

Pharmacological approaches aimed at enhancing the incretin effect in T2DM have been pursued. ${ }^{4}$ Two main classes of incretin therapies are now in use: glucagon-like peptide-1 (GLP-1) receptor agonists and dipeptidyl peptidase-4 (DPP-4) inhibitors. GLP-1 receptor agonists mimic the effects of endogenous GLP-1; they stimulate glucosemedicated insulin secretion and suppress glucagon secretion (Box 1). But, unlike DPP-4 inhibitors, they have the additional clinical benefits of delaying gastric emptying and decreasing appetite.

The Therapeutic Goods Administration has approved the use of some incretin therapies (the DPP-4 inhibitor saxagliptin and two GLP-1 receptor agonists, exenatide and lixisenatide) as adjunctive therapy in patients with T2DM who have inadequate glycaemic control while taking oral hypoglycaemic therapy and basal insulin. To date, these therapies have not been listed on the Pharmaceutical Benefits Scheme for this indication. Data on the combination of DPP-4 inhibitors and basal insulin have recently been reviewed elsewhere; ${ }^{5}$ they reduce glycated haemoglobin $\left(\mathrm{HbA}_{1 \mathrm{c}}\right)$ levels but have no significant effect on

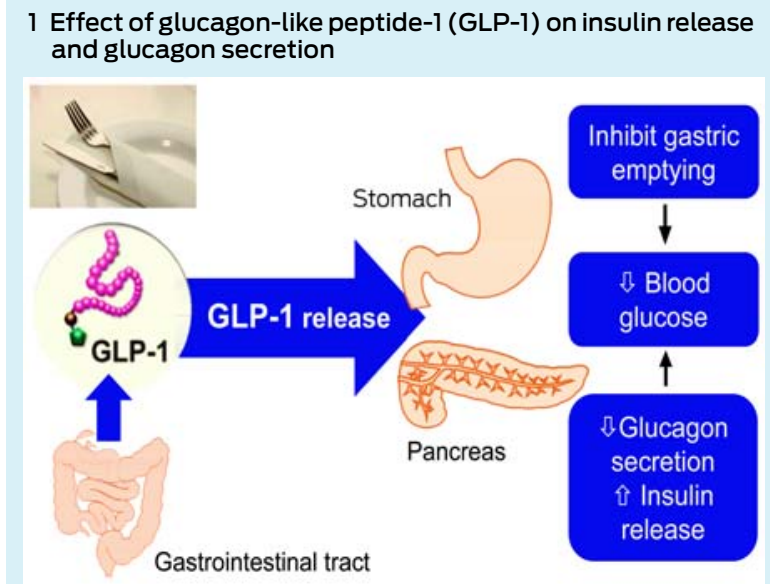

GLP-1 is released within minutes of eating a meal, stimulating insulin release and suppressing glucagon secretion.
- Type 2 diabetes mellitus (T2DM) is progressive; the more intensively it is treated, the greater is the risk of hypoglycaemia and weight gain. Achieving treatment intensification while mitigating these risks presents a challenge to patient management.

- Basal insulins provide control of fasting glucose; however, their utility in the control of postprandial glucose excursions is limited.

- Glucagon-like peptide-1 (GLP-1) receptor agonists stimulate glucose-medicated insulin secretion, suppress glucagon secretion, delay gastric emptying and decrease appetite. Use of GLP-1 receptor agonists in combination therapy with basal insulin offers an alternative approach to intensification of insulin therapy.

- Prospective interventional trials demonstrate that GLP-1 receptor agonists added to basal insulin decrease postprandial glucose levels, lower $\mathrm{HbA}_{1 c}$ levels, decrease weight and lower basal insulin requirements without increasing the risk of major hypoglycaemic events.

- The current clinical data are limited by the lack of any data on the long-term effects of GLP-1 receptor agonists over additional prandial regimens; they may be beneficial or deleterious.

- Although cost, gastrointestinal side effects and long-term safety should be taken into account when considering this combination, it appears to be growing in popularity and is likely to be an important therapeutic option for T2DM in the future.

weight. The pharmacological rationale and clinical evidence for combining GLP-1 receptor agonists with basal insulin are presented below.

\section{Pharmacological rationale}

Basal insulins provide control of fasting glucose; however, their utility in the control of postprandial glucose excursions is limited. Current treatment algorithms advocate the addition of prandial insulin in patients who have not reached their glycaemic targets with basal insulin. T2DM is characterised by impaired insulin secretion, inappropriately high glucagon secretion and increased insulin resistance. Exogenous insulin addresses only one aspect of this pathophysiology. GLP-1 receptor agonists suppress glucagon secretion by $\alpha$ cells, suppress appetite and delay gastric emptying. These effects decrease postprandial glucose excursions, potentially negating the need for prandial insulin. Based on the known mechanisms of action of GLP-1 receptor agonists, their use in combination therapy with basal insulin might offer an alternative approach to aid in maximising $\mathrm{HbA}_{1 \mathrm{c}}$ control, while managing body weight and minimising the risk of hypoglycaemia. 
2 Randomised controlled clinical studies evaluating glucagon-like peptide-1 receptor agonists as add-on therapy to basal insulin in type 2 diabetes mellitus patients for 6 months or more

\begin{tabular}{|c|c|c|c|c|c|c|}
\hline & Buse et $\mathrm{al}^{15}$ & Riddle et al $^{16}$ & Seino et $\mathrm{al}^{17}$ & Riddle et $\mathrm{al}^{18}$ & Riddle et al $^{19}$ & Rosenstock et $\mathrm{al}^{20}$ \\
\hline Study name & & & GetGoal-L-Asia & GetGoal-Duo 1 & GetGoal-L & HARMONY 6 \\
\hline Design & $\begin{array}{l}\mathrm{R}, \mathrm{DB}, \mathrm{PC}, \mathrm{PG}, \mathrm{MC} \\
30 \text { weeks; } n=259\end{array}$ & $\begin{array}{l}\text { R, DB, PC, PG; } \\
24 \text { weeks; } n=34\end{array}$ & $\begin{array}{l}\mathrm{R}, \mathrm{DB}, \mathrm{PC}, \mathrm{PG}, \mathrm{MC} \\
24 \text { weeks; } n=311\end{array}$ & $\begin{array}{l}\mathrm{R}, \mathrm{DB}, \mathrm{PC}, \mathrm{PG}, \mathrm{MC} \\
24 \text { weeks; } n=446\end{array}$ & $\begin{array}{l}\mathrm{R}, \mathrm{DB}, \mathrm{PC}, \mathrm{PG}, \mathrm{MC} \\
24 \text { weeks; } n=495\end{array}$ & $\begin{array}{l}\mathrm{R}, \mathrm{DB}, \mathrm{AC}, \mathrm{PG}, \mathrm{MC} \\
26 \text { weeks; } n=557\end{array}$ \\
\hline Intervention & $\begin{array}{l}\text { Insulin glargine }+ \\
\text { exenatide }(10 \mu g \text { twice } \\
\text { daily }) \pm \text { metformin } \\
\text { and/or pioglitazone } \\
(n=137)\end{array}$ & $\begin{array}{l}\text { Metformin + exenatide } \\
\text { ( } 5-10 \mu g \text { twice daily) } \\
+ \text { insulin glargine } \\
(0.50 \text { units } / \mathrm{kg}) \\
(n=17)\end{array}$ & $\begin{array}{l}\text { Basal insulin } \\
\pm \text { sulfonylurea } \\
+ \text { lixisenatide } \\
(20 \mu g \text { once daily) } \\
(n=154)\end{array}$ & $\begin{array}{l}\text { Insulin glargine } \\
+ \text { lixisenatide } \\
\text { ( } 20 \mu g \text { once daily) } \\
\pm \text { metformin and/or } \\
\text { thiazolidinedione } \\
(n=223)\end{array}$ & $\begin{array}{l}\text { Basal insulin } \\
\pm \text { metformin } \\
+ \text { lixisenatide } \\
(20 \mu g \text { once daily }) \\
(n=328)\end{array}$ & $\begin{array}{l}\text { Basal insulin ffl oral } \\
\text { agents + albiglutide* } \\
(30-50 \mathrm{mg} / \text { week }) \\
(n=279)\end{array}$ \\
\hline Control & $\begin{array}{l}\text { Insulin glargine }+ \\
\text { placebo } \pm \text { metformin } \\
\text { and/or pioglitazone } \\
(n=122)\end{array}$ & $\begin{array}{l}\text { Metformin + placebo } \\
+ \text { insulin glargine } \\
\text { ( } 0.56 \text { units } / \mathrm{kg}) \\
(n=17)\end{array}$ & $\begin{array}{l}\text { Basal insulin } \pm \\
\text { sulfonylurea }+ \text { placebo } \\
(n=157)\end{array}$ & $\begin{array}{l}\text { Insulin glargine }+ \\
\text { placebo } \pm \text { metformin } \\
\text { and/or } \\
\text { thiazolidinedione } \\
(n=223)\end{array}$ & $\begin{array}{l}\text { Basal insulin } \pm \\
\text { metformin + placebo } \\
(n=167)\end{array}$ & $\begin{array}{l}\text { Basal insulin } \pm \text { oral } \\
\text { agents + prandial } \\
\text { insulin lispro }(n=278)\end{array}$ \\
\hline \multirow{3}{*}{$\begin{array}{l}\text { Primary end point: } \\
\text { mean change in } \\
\text { glycated haemoglobin } \\
\text { from baseline, \% }\end{array}$} & Exenatide: - 1.74 & \multirow[t]{3}{*}{ No data presented } & Lixisenatide: - 0.77 & Lixisenatide: - 0.71 & Lixisenatide: - 0.74 & Albiglutide: - 0.82 \\
\hline & Placebo: - 1.04 & & Placebo: + 0.11 & Placebo: - 0.40 & Placebo: - 0.38 & Insulin lispro: - 0.66 \\
\hline & Diff: - $0.69(P<0.001)$ & & $\begin{array}{l}\text { Diff: }-0.88 \\
(P<0.0001)\end{array}$ & $\begin{array}{l}\text { Diff: }-0.32 \\
(P<0.0001)\end{array}$ & $\begin{array}{l}\text { Diff: }-0.36 \\
(P<0.0002)\end{array}$ & Diff: - $0.16(P<0.0001)$ \\
\hline \multirow[t]{2}{*}{$\begin{array}{l}\text { Mean baseline body } \\
\text { weight, kg }\end{array}$} & Exenatide: $95.4 \pm 20.4$ & \multirow[t]{2}{*}{ No data presented } & Lixisenatide: $65.9 \pm 13$ & $\begin{array}{l}\text { Lixisenatide: } \\
86.8 \pm 20.4\end{array}$ & Lixisenatide: $87.4 \pm 20$ & \multirow[t]{2}{*}{ No data presented } \\
\hline & Placebo: $93.4 \pm 21.4$ & & Placebo: $65.6 \pm 12.5$ & Placebo: $87.3 \pm 21.8$ & Placebo: $89.1 \pm 21$ & \\
\hline \multirow{3}{*}{$\begin{array}{l}\text { Mean change in body } \\
\text { weight from baseline, } \\
\text { kg }\end{array}$} & Exenatide: - 1.78 & Exenatide: +0.4 & Lixisenatide: - 0.38 & Lixisenatide: + 0.28 & Lixisenatide: - 1.80 & Albiglutide: - 0.73 \\
\hline & Placebo: + 0.96 & Placebo: + 4.1 & Placebo: + 0.06 & Placebo: + 1.16 & Placebo: - 0.52 & Insulin lispro: + 0.81 \\
\hline & Diff: $-2.74 ; P<0.001$ & Diff: $-3.7 ; P<0.01$ & Diff: $-0.43 ; P=0.08$ & Diff: $-0.89 ; P=0.0012$ & Diff: $-1.28 ; P<0.0001$ & Diff: $-1.54 ; P<0.0001$ \\
\hline \multirow{3}{*}{$\begin{array}{l}\text { Mean change in fasting } \\
\text { plasma glucose level } \\
\text { from baseline, } \mathrm{mmol} / \mathrm{L}\end{array}$} & Exenatide: - 1.6 & \multirow[t]{3}{*}{ No data presented } & Lixisenatide: - 0.42 & Lixisenatide: + 0.34 & Lixisenatide: - 0.6 & Albiglutide: - 0.99 \\
\hline & Placebo: - 1.5 & & Placebo: + 0.25 & Placebo: + 0.46 & Placebo: - 0.6 & Insulin lispro: - 0.72 \\
\hline & Diff: $-0.1 ; P=0.630$ & & Diff: $-0.67 ; P=0.0187$ & Diff: $-0.12 ; P=0.514$ & Diff: 0 & Diff: $-0.27 ; P=0.2390$ \\
\hline \multirow{3}{*}{$\begin{array}{l}\text { Mean change in } \\
\text { morning 2-hour } \\
\text { postprandial glucose } \\
\text { level from baseline, } \\
\text { mmol/L }\end{array}$} & Exenatide: -2.0 & \multirow[t]{3}{*}{ No data presented } & Lixisenatide: - 7.96 & Lixisenatide: - 3.09 & Lixisenatide: -5.54 & \multirow[t]{3}{*}{ No data presented } \\
\hline & Placebo: - 0.2 & & Placebo: - 0.14 & Placebo: + 0.08 & Placebo: - 1.72 & \\
\hline & Diff: - 1.8; $P<0.001$ & & Diff: - 7.83; $P<0.0001$ & Diff: - 3.16; $P<0.0001$ & Diff: - 3.81; $P<0.0001$ & \\
\hline \multirow[t]{2}{*}{ Insulin dose, units/day } & $\begin{array}{l}\text { Exenatide: baseline, } \\
\text { 49.5; change, } \uparrow 13\end{array}$ & $\begin{array}{l}\text { Exenatide: baseline, } \\
\text { nr; change, } \uparrow 0.50\end{array}$ & $\begin{array}{l}\text { Lixisenatide: baseline, } \\
24.9 \text {; change, } \downarrow 1.39\end{array}$ & $\begin{array}{l}\text { Lixisenatide: baseline, } \\
\text { 43.3; change, } \uparrow 3.0\end{array}$ & $\begin{array}{l}\text { Lixisenatide: baseline, } \\
54 \text {; change, } \downarrow 6\end{array}$ & $\begin{array}{l}\text { Albiglutide: } \mathrm{nr} \\
\text { change, } \uparrow 5\end{array}$ \\
\hline & $\begin{array}{l}\text { Placebo: } 47.4 \\
\text { change, } \uparrow 20\end{array}$ & $\begin{array}{l}\text { Placebo: } \mathrm{nr} \\
\text { change, } \uparrow 0.56\end{array}$ & $\begin{array}{l}\text { Placebo: } 24.1 \text {; } \\
\text { change, } \downarrow 0.11\end{array}$ & $\begin{array}{l}\text { Placebo: } 44.2 \\
\text { change, } \uparrow 5.0\end{array}$ & $\begin{array}{l}\text { Placebo: } 58 \text {; } \\
\text { change, } \downarrow 2\end{array}$ & $\begin{array}{l}\text { Insulin lispro: nr; } \\
\text { change, } \uparrow 7\end{array}$ \\
\hline \multirow{2}{*}{$\begin{array}{l}\text { Discontinuation due to } \\
\text { treatment-emergent } \\
\text { adverse events }\end{array}$} & Exenatide: 13 (9\%) & \multirow[t]{2}{*}{ No data presented } & Lixisenatide: 14 (9\%) & \multirow[t]{2}{*}{ No data presented } & Lixisenatide: 25 (8\%) & \multirow[t]{2}{*}{ No data presented } \\
\hline & Placebo: 1 (1\%) & & Placebo: 5 (3\%) & & Placebo: 8 (5\%) & \\
\hline \multicolumn{7}{|l|}{$\begin{array}{l}\text { Number of patients } \\
\text { with hypoglycaemia }\end{array}$} \\
\hline \multirow[t]{2}{*}{ Minor events ${ }^{\dagger}$} & Exenatide: 34 (25\%) & Exenatide: 9 (53\%) & & & & \\
\hline & Placebo: 35 (29\%) & Placebo: 7 (41\%) & & & & \\
\hline \multirow[t]{2}{*}{ Symptomatic events ${ }^{\ddagger}$} & & & $\begin{array}{l}\text { Lixisenatide: } \\
66(43 \%)\end{array}$ & $\begin{array}{l}\text { Lixisenatide: } \\
45(20 \%)\end{array}$ & $\begin{array}{l}\text { Lixisenatide: } \\
87(27 \%)\end{array}$ & $\begin{array}{l}\text { Albiglutide: } \\
61(22 \%)\end{array}$ \\
\hline & & & Placebo: 37 (24\%) & Placebo: 27 (12\%) & Placebo: 35 (21\%) & Insulin lispro: 66 (24\%) \\
\hline \multirow[t]{2}{*}{ Major events ${ }^{5}$} & Exenatide: 0 & Exenatide: 0 & Lixisenatide: 0 & Lixisenatide: 1 (0.4\%) & Lixisenatide: 4 (1\%) & Albiglutide: $\mathrm{nr}$ \\
\hline & Placebo: 1 (1\%) & Placebo: 0 & Placebo: 0 & Placebo: 0 & Placebo: 0 & Insulin lispro: nr \\
\hline
\end{tabular}

$\mathrm{AC}=$ active control. change $=$ average increase or decrease in insulin dose (units/day). $\mathrm{DB}=$ double blind. Diff $=$ between-group difference. $\mathrm{MC}=$ multicentre. $\mathrm{nr}=$ not reported.

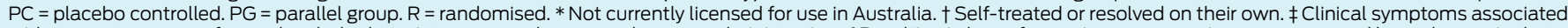

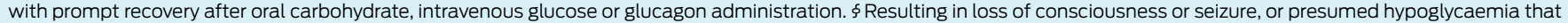
required the assistance of another person.

Although all GLP-1 receptor agonists share the same basic mechanism of action, differences in their pharmacokinetics result in variations in their effects on fasting blood glucose and postprandial glucose excursions. ${ }^{6}$ Data suggest that continuous GLP-1 exposure might downregulate effects on gastric emptying, with a subsequent impact on postprandial glucose excursions. ${ }^{6}$ Short-acting GLP-1 receptor agonists (eg, exenatide, lixisenatide), which provide intermittent GLP-1 exposure, have a greater effect on postprandial glucose excursions, ${ }^{7-10}$ suggesting that their use could, in theory, better complement the activity of basal insulin. Short-acting GLP-1 receptor agonists exert their most pronounced postprandial glucose effects following the first meal after drug administration. Clinical studies are needed to verify whether there will be any advantage to administering lixisenatide in conjunction with the largest meal of the day.

\section{Clinical evidence}

Clinical data from prospective and retrospective studies evaluating the efficacy of exenatide in combination with 
basal insulin have been summarised in the literature. ${ }^{11}$ The evidence suggests that this combination provides improvements in $\mathrm{HbA}_{1 \mathrm{c}}$ and postprandial glucose levels, with concomitant weight loss and no marked increase in the risk of hypoglycaemia. ${ }^{11}$

Retrospective observational and clinical practice studies examining GLP-1 receptor agonists combined with basal insulin have consistently shown improvements in $\mathrm{HbA}_{1 \mathrm{c}}$ levels and body weight, but also increased reports of gastrointestinal side effects. ${ }^{12}$ Despite their limitations, collectively, these studies provide insight into real-world use of this combination over a period of up to 4 years. They also demonstrate frequent use of this combination in clinical practice before it has received regulatory approval in other markets. For example, the Association of British Clinical Diabetologists real-world audit, in which 315 contributors from 126 centres across the United Kingdom provided data, showed that of the 4857 patients treated with exenatide, 1921 (39.6\%) had used it in combination with insulin before this combination was registered. ${ }^{13}$ Patients on combination therapy comprised those for whom insulin had been continued at exenatide initiation $(n=1257)$ as well as those for whom insulin was started after exenatide initiation $(n=664)$. The latter were not included in the data analyses. Over the 12-month period of the audit, adding exenatide to patients continuing on insulin resulted in a mean $\mathrm{HbA}_{1 \mathrm{c}}$ level reduction of $0.51 \%$, weight reduction of $5.8 \mathrm{~kg}$, an insulin dose reduction of 42 units/day and $16.6 \%$ of patients stopping insulin use.

Systematic reviews of prospective interventional data, from studies of differing sizes and durations, conclude that the use of GLP-1 receptor agonists as add-on therapy to basal insulin has demonstrable advantages in terms of additional lowering of $\mathrm{HbA}_{1 \mathrm{c}}$ levels without major risk for hypoglycaemia, lower basal insulin requirements, decreased postprandial glucose levels (with or without fasting plasma glucose decreases) and weight loss. ${ }^{12,14}$ The effects of adding exenatide once weekly to insulin glargine have not yet been assessed in a clinical trial. Box 2 provides a summary of available data from randomised controlled clinical studies in which this combination has been evaluated for 6 months or more. ${ }^{15-20}$

The question of whether there is a continuing role for GLP-1 receptor agonists when prandial insulin becomes necessary has not yet been answered. Randomised controlled trials (RCTs) have only included patients using basal insulin; however, observational studies have included patients using basal alone, ${ }^{21}$ basal plus prandial, ${ }^{22}$ or premixed insulin. ${ }^{23}$ Of note, in studies that included prandial

3 Potential advantages and concerns of combining a glucagon-like peptide-1 receptor agonist with basal insulin

Advantages:

- reduced exogenous insulin requirement

weight maintenance or loss

ability to target both fasting and postprandial

hyperglycaemia

relatively low risk of hypoglycaemia

Concerns:

adverse effects

impact on absorption of other drugs

fixed dosing schedules

costs - not currently PBS-listed for this indication or premixed insulin, the doses of prandial insulin in particular were decreased, whereas doses of basal insulin generally remained constant, lending further support to the rationale for combining a GLP-1 receptor agonist with basal insulin.

\section{Potential concerns}

The potential benefits of combining a GLP-1 receptor agonist with basal insulin need to be weighed against tolerability, safety and costs (Box 3). In addition, fixed dosing schedules and the potential impact on the absorption of other drugs should be taken into account.

The most commonly reported adverse events with GLP1 receptor agonists are gastrointestinal; predominantly nausea, vomiting and diarrhoea. Although these adverse events are reportedly worst at the beginning of treatment and reduce over the duration of the study, they still account for a high proportion of withdrawals from trials. ${ }^{24} \mathrm{~A}$ similar gastrointestinal tolerability profile has been noted in studies combining GLP-1 receptor agonists with basal insulin, with nausea being the predominant gastrointestinal adverse event (exenatide, $41 \% \mathrm{v}$ placebo, $8 \%{ }^{15}$ lixisenatide, $39.6 \% \mathrm{v}$ placebo, $4.5 \%{ }^{17}$ ).

Compared with placebo, higher discontinuation rates due to treatment-emergent adverse events were reported in the basal insulin combination studies with exenatide $(9 \% \mathrm{v}$ placebo, $1 \%)^{15}$ and lixisenatide $(9.1 \% \mathrm{v}$ placebo, $3.2 \%) .{ }^{17}$ The current clinical data are limited by the lack of any longterm safety data. In retrospective studies, the frequency of adverse events as a whole was low; however, discontinuation rates due to adverse events were higher (22\%-27\%) than have been reported in prospective studies. ${ }^{12}$

GLP-1 receptor agonists do not replace the use of insulin. Identifying responders and non-responders is a clinical challenge; no data are available to aid in predicting who will or will not respond. If patients have not responded within a reasonable time frame, such as 3 months, then the GLP-1 receptor agonist should be stopped. A United States-based retrospective cohort study has shown adherence rates for exenatide and liraglutide to be less than $60 \%{ }^{25}$ Thus, before stopping therapy it would be pertinent to discuss compliance and administration issues with the patient.

Debate continues as to the true clinical relevance of the possible association between acute pancreatitis and the use of incretin-based therapies. Data from postmarketing reports are conflicting. Two recent studies have examined DPP-4 inhibitors and GLP-1 receptor agonists. ${ }^{26,27}$ In both studies, the majority of the body of evidence was built on the association between pathological changes of the pancreas and the use of DPP-4 inhibitors. The data presented on GLP-1 receptor agonists were limited in terms of sample size ${ }^{26}$ or relative risk. ${ }^{27}$ No cases of pancreatitis have been reported in RCTs of GLP-1 receptor agonists combined with basal insulin. ${ }^{12}$ Diabetes itself places patients at increased risk of developing pancreatitis; thus, it remains to be determined whether the reports of acute pancreatitis are related to the patient's underlying disease. The issue has come under considerable regulatory scrutiny around the world but, as yet, no conclusions have been reached. The issue is complex and definitive answers will 
4 Combining glucagon-like peptide-1 (GLP-1) receptor agonists with basal insulin: practical considerations for the Australian clinician

- Four GLP-1 receptor agonists are currently registered in Australia:

\begin{tabular}{lcc} 
GLP-1 receptor agonist & $\begin{array}{c}\text { Combination with } \\
\text { oral antidiabetic drugs }\end{array}$ & $\begin{array}{c}\text { Combination with } \\
\text { basal insulin }\end{array}$ \\
\hline Exenatide* twice daily & TGA approved; PBS listed & TGA approved \\
Exenatide $^{\dagger}$ once weekly & TGA approved & \\
Liraglutide $^{\ddagger}$ once daily & TGA approved & TGA approved \\
Lixisenatide $^{\delta}$ once daily & TGA approved & TG \\
\hline
\end{tabular}

PBS = Pharmaceutical Benefits Scheme. TGA = Therapeutic Goods Administration. * Byetta, Bristol-Myers Squibb. † Bydureon, Bristol-Myers Squibb. ¥ Victoza, Novo Nordisk. \$ Lyxumia, Sanofi.

When commencing a GLP-1 receptor agonist in combination with basal insulin, trial and retrospective data suggest that only small reductions in insulin dose (if any) are initially required.

- Clinicians must take a proactive approach in warning patients regarding gastrointestinal side effects and intolerance.

GLP-1 receptor agonists do not replace the use of insulin. If patients have not responded within a reasonable time frame, then the GLP-1 receptor agonist should be stopped if compliance and administration issues have been ruled out.

only come from longer-term data. In the meantime, it is recommended that if pancreatitis is suspected, GLP-1 receptor agonists should be discontinued and, if confirmed, not restarted. GLP-1 receptor agonists should be avoided in patients with a history of pancreatitis.

\section{Conclusion}

The available data present a strong pharmacological rationale for the combined use of GLP-1 receptor agonists with basal insulin, and these are supported by positive results from short-term clinical trials. Box 4 summarises practical considerations that Australian clinicians should be aware of when considering the use of GLP-1 receptor agonists in combination with basal insulin. The combination may be of particular value for patients who are overweight and for those in whom hypoglycaemia is an especially worrisome potential adverse effect. Although cost and gastrointestinal side effect profiles should be taken into account when considering this combination, it is likely to be an important therapeutic option for T2DM in the future.

Acknowledgements: This work has been carried out with financial support from Sanofi Australia. The sponsor reviewed the final manuscript before submission. We acknowledge the editorial assistance provided by a professional medical writer, Hazel Palmer of Scius Solutions, whose contribution was funded by Sanofi Australia.

Competing interests: Neale Cohen has received educational grants from Sanofi, MSD and Medtronic, honoraria for lectures from Sanofi, Eli Lilly, Novo Nordisk, AstraZeneca, Medtronic, MSD and Bristol-Myers Squibb, and travel funding from Sanofi, Novo Nordisk, Eli Lilly, MSD and Abbott. Ralph Audehm has been reimbursed for participation on advisory boards for AstraZeneca and Sanofi, and has received consultancy fees from Novo Nordisk, speaker's fees from Sanofi and Novo Nordisk and travel funding from Eli Lilly. Elaine Pretorius has received honoraria for educational lectures from Eli Lilly, Sanofi, Novo Nordisk and MSD, and travel funding from Sanofi, Novo Nordisk and Eli Lilly. Joey Kaye has received honoraria for educational lectures from Eli Lilly and Novo Nordisk, and travel funding from MSD and Sanofi. Leon Chapman has received honoraria from

Novartis, Ely Lilly, Sanofi, AstraZeneca, Boehringer Ingelheim, Bristol-Myers Squibb, Novo Nordisk and MSD for educational lectures. Stephen Colagiuri has received consultancy fees from Sanofi, Novo Nordisk, Servier, MSD, AstraZeneca, Bristol-Myers Squibb, Roche Diagnostics, Eli Lilly and Medtronic, speaker's fees from Sanofi, Novo Nordisk, Servier, MSD, AstraZeneca, Bristol-Myers Squibb, Roche Diagnostics and Eli Lilly, and honoraria for the development of educational presentations from Novo Nordisk and MSD.

1 Miller ME, Bonds DE, Gerstein HC, et al. The effects of baseline characteristics, glycaemia treatment approach, and glycated haemoglobin concentration on the risk of severe hypoglycaemia: post hoc epidemiological analysis of the ACCORD study. BMJ 2010; 340: b5444.

2 Gerstein HC, Miller ME, Byington RP, et al. Effects of intensive glucose lowering in type 2 diabetes. N Engl J Med 2008; 358: 2545-2559.
3 Gerstein HC, Miller ME, Genuth S, et al. Long-term effects of intensive glucose lowering on cardiovascular outcomes. N Engl J Med 2011; 364: 818-828.

4 Inzucchi SE, McGuire DK. New drugs for the treatment of diabetes: part II: incretin-based therapy and beyond. Circulation 2008; 117: 574-584.

5 Rizos EC, Ntzani EE, Papanas N, et al. Combination therapies of DPP4 inhibitors and GLPI analogues with insulin in type 2 diabetic patients: a systematic review. Curr Vasc Pharmacol 2012; Jun 22 [Epub ahead of print].

6 Fineman MS, Cirincione BB, Maggs D, Diamant M. GLP-1 based therapies: differential effects on fasting and postprandial glucose. Diabetes Obes Metab 2012; 14: 675-688.

7 Blevins T, Pullman J, Malloy J, et al. DURATION-5: exenatide once weekly resulted in greater improvements in glycemic control compared with exenatide twice daily in patients with type 2 diabetes. J Clin Endocrinol Metab 2011; 96: 1301-1310.

8 Drucker DJ, Buse JB, Taylor K, et al. Exenatide once weekly versus twice daily for the treatment of type 2 diabetes: a randomised, open-label, non-inferiority study. Lancet 2008; 372: 1240-1250.

9 Buse JB, Rosenstock J, Sesti G, et al. Liraglutide once a day versus exenatide twice a day for type 2 diabetes: a 26-week randomised, parallel-group, multinational, open-label trial (LEAD-6). Lancet 2009; 374: 39-47.

10 Kapitza C, Coester HV, Poitiers F, et al. Pharmacodynamic characteristics of lixisenatide once daily versus liraglutide once daily in patients with type 2 diabetes insufficiently controlled on metformin. Diabetes Obes Metab 2013; 15: 642-649.

11 Perfetti R. Combining basal insulin analogs with glucagon-like peptide-1 mimetics. Diabetes Technol Ther 2011; 13: 873-881.

12 Balena R, Hensley IE, Miller S, Barnett AH. Combination therapy with GLP-1 receptor agonists and basal insulin: a systematic review of the literature. Diabetes Obes Metab 2013; 15: 485-502.

13 Thong KY, Jose B, Sukumar N, et al. Safety, efficacy and tolerability of exenatide in combination with insulin in the Association of British Clinical Diabetologists nationwide exenatide audit. Diabetes Obes Metab 2011; 13: 703-710.

14 Berlie H, Hurren KM, Pinelli NR. Glucagon-like peptide-1 receptor agonists as add-on therapy to basal insulin in patients with type 2 diabetes: a systematic review. Diabetes Metab Syndr Obes 2012; 5: 165-174.

15 Buse JB, Bergenstal RM, Glass LC, et al. Use of twice-daily exenatide in basal insulin-treated patients with type 2 diabetes: a randomized, controlled trial. Ann Intern Med 2011; 154: 103-112.

16 Riddle M, Ahmed A, Basu A, et al. Metformin+exenatide+basal insulin: reaching $A l c<6.5 \%$ without weight-gain or serious hypoglycemia [abstract]. Diabetes 2010; 59 Suppl 1A: LB6.

17 Seino Y, Min KW, Niemoeller E, Takami A. Randomized, double-blind, placebocontrolled trial of the once-daily GLP-1 receptor agonist lixisenatide in Asian patients with type 2 diabetes insufficiently controlled on basal insulin with or without a sulfonylurea (GetGoal-L-Asia). Diabetes Obes Metab 2012; 14: 910-917.

18 Riddle MC, Forst T, Aronson R, et al. Adding once-daily lixisenatide for type 2 diabetes inadequately controlled with newly initiated and continuously titrated basal insulin glargine: a 24-week, randomized, placebo-controlled study (GetGoal-Duo 1). Diabetes Care 2013; Apr 25 [Epub ahead of print].

19 Riddle MC, Aronson R, Home P, et al. Adding once-daily lixisenatide for type 2 diabetes inadequately controlled by established basal insulin: a 24-week, randomized, placebo-controlled comparison (GetGoal-L). Diabetes Care 2013; May 6 [Epub ahead of print].

20 Rosenstock J, Ahrén B, Chow F, et al. Once-weekly GLP-1 receptor agonist albiglutide vs titrated prandial lispro added on to titrated basal glargine in type 2 diabetes (T2D) uncontrolled on glargine plus oral agents: similar glycemic control with weight loss and less hypoglycemia. Diabetes 2012; 61 Suppl 1: A15.

21 Yoon NM, Cavaghan MK, Brunelle RL, Roach P. Exenatide added to insulin therapy: a retrospective review of clinical practice over two years in an academic endocrinology outpatient setting. Clin Ther 2009; 31: 1511-1523.

22 Sheffield CA, Kane MP, Busch RS, et al. Safety and efficacy of exenatide in combination with insulin in patients with type 2 diabetes mellitus. Endocr Pract 2008; 14: 285-292.

23 Viswanathan P, Chaudhuri A, Bhatia R, et al. Exenatide therapy in obese patients with type 2 diabetes mellitus treated with insulin. Endocr Pract 2007; 13: 444-450.

24 Vilsboll T, Christensen M, Junker AE, et al. Effects of glucagon-like peptide-] receptor agonists on weight loss: systematic review and meta-analyses of randomised controlled trials. BMJ 2012; 344: d7771.

25 Pelletier EM, Pawaskar M, Smith PJ, et al. Economic outcomes of exenatide vs liraglutide in type 2 diabetes patients in the United States: results from a retrospective claims database analysis. J Med Econ 2012; 15: 1039-1050.

26 Butler AE, Campbell-Thompson M, Gurlo T, et al. Marked expansion of exocrine and endocrine pancreas with incretin therapy in humans with increased exocrine pancreas dysplasia and the potential for glucagon-producing neuroendocrine tumors. Diabetes 2013; 62: 2595-2604.

27 Singh S, Chang HY, Richards TM, et al. Glucagonlike peptide l-based therapies and risk of hospitalization for acute pancreatitis in type 2 diabetes mellitus: a population-based matched case-control study. JAMA Intern Med 2013; 173: 534-539. 